\title{
OPTIMIZATION OF MAYONNAISE EMULSION RECIPE WITH EGG PROTEIN
}

\author{
T. Nosenko, V. Babenko, V. Bakhmach \\ National University of Food Technologies \\ O. Kubaychuk \\ National Aviation University
}

\begin{tabular}{l} 
Key words: \\
Optimization of the \\
formulation \\
Mayonnaise products \\
Refined deodorized oils \\
Egg protein \\
Stability of the emulsion \\
Thermostability \\
\hline
\end{tabular}

Article history:

Received 11.07.2018

Received in revised form

02.08 .2018

Accepted 22.08.2018

Corresponding author:

T. Nosenko

E-mail:

npnuht@ukr.net

\begin{abstract}
The aim of this work was to optimize the formulation of mayonnaise emulsions with liquid egg protein on the basis of the developed special method for determining their stability. Due to the surface-active properties of liquid egg protein and the absence of cholesterol in its composition, it would be worth to develop recipes of mayonnaise sauces containing liquid oils of different fatty acid composition using liquid egg albumin as an emulsifier.

A special method for stability determination of the mayonnaise emulsions of liquid oils with different fatty acid composition and liquid egg protein was developed, which included centrifugation of mayonnaise emulsion samples in a test tube for 5 minutes at $3000 \mathrm{~min}^{-1}$ at $25^{\circ} \mathrm{C}$, exposition in a thermostat for 10 minutes at $55^{\circ} \mathrm{C}$ and next centrifugation at $3000 \mathrm{~min}^{-1}$ during 5 minutes. The formulations of mayonnaises with liquid egg protein were optimized using the index of stability, determined by the developed special method.

The obtained mathematical model can be used by technologists for modifications of component content of mayonnaise recipes. The synergy of the action of emulsifiers egg protein and mustard powder in high-fat emulsions, that had been demonstrated as increasing of emulsion stability, was investigated. The organoleptic and physico-chemical parameters of developed mayonnaise products with egg albumin were studied. It has been found that samples had high quality indices and didn't contain cholesterol. Using of proposed recipes and their optimization allows to expand the assortment of mayonnaises and provides consumers by highquality domestic products. According to the organoleptic and physico-chemical quality parameters, emulsion products with egg albumin, that don't contain cholesterol can be used as a seasoning for salads and various dishes at home and in restaurants.
\end{abstract}

DOI: $10.24263 / 2225-2924-2018-24-4-21$ 


\title{
ОПТИМІЗАЦІЯ РЕЦЕПТУРИ МАЙОНЕЗНИХ ЕМУЛЬСІЙ 3 ЯєЧнИМ БІЛКОМ
}

\author{
T.T. Носенко, В.I. Бабенко, В.О. Бахмач \\ Національний університет харчових технологій \\ O.О. Кубайчук \\ Наиіональний авіаційний університет
}

3 метою оптимізації рецептури майонезних емульсій з використанням рідкого яєчного білка розроблено спеціальний метод визначення їх стійкості. Зважаючи на поверхнево-активні властивості рідкого яєчного білка та відсутність у його складі холестерину, виникає потреба розроблення реиептур майонезних соусів на основі рідких олій різного жирнокислотного складу з використанням рідкого яєчного білка як емульгатора.

Розроблено спечіальний метод визначення стійкості емульсії для майонезних емульсій на основі рідких олій різного жирнокислотного складу з рідким яєчним білком, що передбачає иентрифугування зразка майонезної емульсії в пробіриі протягом 5 хв при $3000 \times 6^{-1}$ при температурі $25^{\circ} \mathrm{C}$ та витримуванні в термостаті 10 хв при $55^{\circ} \mathrm{C}$ і подальшим иентрифугуванням 5 хв. Оптимізовано рецептуру майонезних продуктів з використанням рідкого яєчного білка за показником стійкості готової емульсії, визначеного за допомогою розробленого спечіального методу.

Отримана математична модель може бути використана технологами на виробництві при модифікаціях вмісту компонентів у технології майонезів. Досліджено синергізм дії емульгаторів у високожирних емульсіях: яєчного білка та гірчичного порошку, щзо проявляється у підвищенні стійкості емульсії. Розроблені майонезні продукти з яєчним білком досліджувалися за органолептичними та фізико-хімічними показниками. Встановлено, щзо зразки мають високі показники якості, не містять холестерину. Використання запропонованих рецептур та їх оптимізація дає змогу розширити асортимент продукиії й забезпечить спожсивачів якісним вітчизняним продуктом. Розроблені майонези можуть бути використані для безпосереднього вжсивання 6 їжу як приправа до салатів і різних страв у домашній кулінарії та підприємствах ресторанного господарства.

Ключові слова: оптимізація рецептури, майонезні продукти, рафіновані дезодоровані олії, яєчний білок, стійкість емульсії, термостабільність.

Постановка проблеми. В Україні майонези та майонезні соуси, а також салатні соуси виробляють харчові підприємства у широкому асортименті. Соуси добре доповнюють і урізноманітнюють смак різних страв, роблять їх соковитими, підвищують поживні та смакові властивості. Вагома частина соусів на ринку — це емульсійні продукти рослинного походження, тобто без додавання молочних та яйцепродуктів.

До їх складу входять: вода питна, олія соняшникова рафінована дезодорована, крохмаль модифікований, цукор білий, сіль кухонна, кислота оцтова, 
стабілізатори (камеді: рожкового дерева, гуару, ксантану), консерванти солі сорбінової або бензойної кислот, ароматизатори яєчного жовтка та гірчиці, екстракт перцю чорного, кислота лимонна, бета-каротин тощо. Такі соуси відрізняються високими органолептичними властивостями, хоча вони не містять рецептурних компонентів тваринного походження і характеризуються низьким вмістом вуглеводів. У них практично відсутні білки, мають незначний вміст жиру, разом з цим наявні консерванти та різні хімічні ароматизатори.

Проте основна сировина для виробництва майонезів і майонезних соусів (яйцепродукти, молокопродукти, рослинні оліі) заслужено відноситься до сировини, що має належну біологічну цінність. Але оскільки деякі вчені вважають, що при вживанні цих продуктів підвищується рівень холестерину в крові, що спричиняє ожиріння та інші хвороби, які скорочують життя людини, то це змушує виробників емульсійних продуктів розробляти рецептури продуктів «без вмісту холестерину», в яких використовують різні стабілізатори, смакові добавки, консерванти, ідентичні натуральним, але отримані шляхом хімічного синтезу. Такі компоненти не тільки знижують біологічну цінність майонезних соусів, але й можуть бути навіть небезпечними для здоров'я людини.

Тому перспективним напрямком при виробництві емульсійних продуктів $\epsilon$ пошук і використання вітчизняних натуральних рецептурних інгредієнтів, що підвищують біологічну цінність емульсійного продукту, оптимізація рецептури майонезних емульсій, що забезпечить утворення не тільки необхідної консистенції та високої стійкості емульсії. Для оптимізації цього необхідно було розробити спеціальний метод визначення стійкості емульсії як критерію оптимізації, оскільки цей важливий показник якості майонезних емульсій не завжди можна визначити за стандартною методикою.

Аналіз останніх досліджень і публікацій. За даними [2, с. 40], рідкий яєчний білок містить $87,9 \%$ вологи, 10,6\% білка, $0,9 \%$ вуглеводнів і в ньому практично відсутній жир. Яєчні білки не містять холестерину, а навіть мають в собі речовини, які сприяють зменшенню рівня «поганого» холестерину в крові [3, с. 169]. При цьому білок містить вуглеводи, мінеральні речовини, протеїн і важливі амінокислоти, що організм людини самостійно синтезувати не може; вітаміни групи В, зокрема біотин. Без тваринного білка неможливе живлення й оновлення клітин і тканин організму. Яєчний білок - низькокалорійне джерело повноцінних білків. У 100 г яєчного білка міститься близько 50 ккал і 11 г протеїну, тоді як у молоці, відповідно, 69 ккал і 4 г, в яловичині середньої жирності - 218 ккал і 17 г. Білок на 93,7\% засвоюється організмом людини (для риби цей показник - 76\%, для яловичини $-73,3 \%$, для квасолі всього $58 \%)$ [3, с. 170].

Білок курячого яйця прийнятий як еталон біологічної цінності для людини завдяки його оптимальному амінокислотному складу і високому рівню засвоюваності. 3 точки зору хімічного складу яєчні продукти являють собою складну структуру, основою якої $є$ протеїново-фосфоліпідний комплекс, при цьому протеїни $\epsilon$ високомолекулярними ПАР, а фосфоліпіди - низькомолекулярними. У молекулі білка є ділянки з ковалентними (розчинними в олії) та 
іонними (розчинними у воді) зв'язками. Прикладами можуть служити амінокислоти, триптофан і фенілаланін у білкової молекулі [3, с. 170].

Білок і жовток яйця мають різний склад протеїнів. Білок складається в основному з білків, в число яких входять овоальбумін, овокональбумін, овоглобулін, лізоцим тощо. Ці протеїни мають такі функціональні властивості білка для виробництва майонезів [4, с. 29] як розчинність у водній фазі, здатність до диспергування, а також бактерицидну дію (лізоцим).

Зважаючи на поверхнево-активні властивості рідкого яєчного білка та на відсутність у його складі холестерину, виникає необхідність розроблення рецептур майонезних соусів на основі рідких олій різного жирнокислотного складу з використанням рідкого яєчного білка як емульгатора. А для оцінювання стійкості емульсії таких майонезних продуктів необхідно розробити спеціальний метод визначення стійкості емульсії. Один із основних показників якості майонезних продуктів - стійкість емульсії, визначають у відсотках незруйнованої емульсії за об’ємом. За відомою методикою [1, с. 4] визначення стійкості емульсії скляну пробірку заповнюють майонезною емульсією до верхньої поділки 10 мл, розміщують у центрифузі та центрифугують 5 хв зі швидкістю $1500 \mathrm{xв}^{-1}$. Потім пробірку витримують у киплячій воді протягом 3 хв та знову центрифугують протягом 5 хв і розраховують відсоток незруйнованої емульсії.

Ця стандартна методика не може бути використана для майонезних емульсій за розробленими рецептурами 3 використанням рідкого яєчного білка як емульгатора, оскільки при нагріванні маси в пробірці за температурі кипіння води $100^{\circ} \mathrm{C}$ яєчний білок денатурується і згорнута маса виштовхується із пробірки, що не дає змоги взагалі визначити показник стійкості емульсії.

Мета дослідження: оптимізація рецептури майонезних емульсій на основі рідких олій різного жирнокислотного складу з використанням рідкого яєчного білка як емульгатора за показником стійкості емульсії, визначеним за допомогою розробленого спеціального методу.

Викладення основних результатів дослідження. При оптимізації рецептури майонезних емульсій 3 використанням рідкого яєчного білка як емульгатора та розробленні спеціального методу визначення їх стійкості для їх приготування було використано зразки рідких рослинних олій з різним жирнокислотним складом. Груповий жирнокислотний склад зразків рафінованих дезодорованих олій за даними виробників представлено в табл. 1.

Таблиия 1. Груповий жирнокислотний склад зразків олій

\begin{tabular}{|c|c|c|c|c|c|}
\hline \multirow{2}{*}{$\begin{array}{c}\text { № } \\
\text { п/п }\end{array}$} & Назва & \multicolumn{4}{|c|}{ Олія рафінована дезодорована } \\
\cline { 3 - 6 } & $\begin{array}{c}\text { соняшников } \\
\text { a MIGROS }\end{array}$ & $\begin{array}{c}\text { соняшникова } \\
\text { високоолеїнова } \\
\text { ВIO СООР }\end{array}$ & $\begin{array}{c}\text { apaxicoва } \\
\text { MIGROS }\end{array}$ & $\begin{array}{c}\text { ріпакова високо- } \\
\text { олеїнова MIGROS }\end{array}$ \\
\hline 1 & Насичені кислоти,\% & 11,5 & 9,2 & 20,7 & 6,9 \\
\hline 2 & $\begin{array}{c}\text { Мононенасичені } \\
\text { кислоти,\% }\end{array}$ & 27,6 & 83,9 & 58,6 & 80,5 \\
\hline 3 & $\begin{array}{c}\text { Поліненасичені } \\
\text { кислоти,\% }\end{array}$ & 60,9 & 6,9 & 20,7 & 12,6 \\
\hline
\end{tabular}


У лабораторії кафедри технології жирів і парфумерно-косметичних продуктів НУХТ визначалися основні показники якості зразків рафінованих дезодорованих олій за стандартними методиками.

Показники якості зразків рафінованих дезодорованих олій представлені у табл. 2.

\section{Таблиия 2. Показники якості зразків рафінованих дезодорованих олій}

\begin{tabular}{|c|c|c|c|c|c|}
\hline \multirow[b]{2}{*}{$\begin{array}{l}\text { № } \\
\Pi / \Pi\end{array}$} & \multirow[b]{2}{*}{$\begin{array}{c}\text { Найменування } \\
\text { показників }\end{array}$} & \multicolumn{4}{|c|}{ Олія рафінована дезодорована } \\
\hline & & $\begin{array}{c}\text { соняшникова } \\
\text { MIGROS }\end{array}$ & $\begin{array}{c}\text { соняшникова } \\
\text { високоолеїнова } \\
\text { ВІО СООР }\end{array}$ & $\begin{array}{l}\text { apaxicoва } \\
\text { MIGROS }\end{array}$ & \begin{tabular}{|} 
ріпакова високо- \\
олеїнова MIGROS
\end{tabular} \\
\hline 1 & Прозорість & $\begin{array}{c}\text { Прозора, без } \\
\text { осаду }\end{array}$ & $\begin{array}{c}\text { Прозора, без } \\
\text { осаду }\end{array}$ & $\begin{array}{c}\text { Прозора, без } \\
\text { осаду }\end{array}$ & $\begin{array}{c}\text { Прозора, без } \\
\text { осаду }\end{array}$ \\
\hline 2. & Смак і запах & \begin{tabular}{|c|} 
Смак \\
знеособленої \\
олії, без запаху
\end{tabular} & $\begin{array}{c}\text { Смак } \\
\text { знеособленої олії, } \\
\text { без запаху }\end{array}$ & $\begin{array}{c}\text { Смак } \\
\text { знеособленої } \\
\text { олї̈, без запаху }\end{array}$ & $\begin{array}{c}\text { Смак } \\
\text { знеособленої олії, } \\
\text { без запаху }\end{array}$ \\
\hline 3. & $\begin{array}{c}\text { Колірне число, } \\
\text { мг } \mathrm{J}_{2} \\
\end{array}$ & 10 & 5 & 10 & 5 \\
\hline 4 & $\begin{array}{c}\text { Кислотне число, } \\
\text { мг КОН/г }\end{array}$ & 0,36 & 0,31 & 0,29 & 0,26 \\
\hline 5 & \begin{tabular}{|c} 
Перексидне \\
число , ммоль $1 / 2$ \\
О/кг \\
\end{tabular} & 4,5 & 3,4 & 3,5 & 2,6 \\
\hline
\end{tabular}

Згідно 3 даними, наведеними у табл. 2, зразки за основними показниками якості відповідають вимогам і не перевищують норми показників, встановлені стандартами України для рафінованих дезодорованих олій.

Майонезні емульсії готували на основі зазначених олій за розробленими рецептурами $[2$, с. 40$]$ в лабораторних умовах за традиційною методикою. За рецептурою зважені смакові добавки (сіль, цукор, готову гостру гірчицю) змішували блендером 3 водою при температурі $25^{\circ} \mathrm{C}$ до однорідної маси в хімічному стакані. При постійному перемішуванні вводили рідкий яєчний білок, що одержували шляхом сепарування від жовтка курячих яєць однієї партії. Наступну стадію емульгування проводили 3 охолодженою до $+5^{\circ} \mathrm{C}$ рафінованою дезодорованою олією відповідного зразка, вводячи олію невеликими порціями.

На завершальній стадії змішування майонезної емульсії з кислотою додавали останню по краплях. Потім декілька хвилин проводили завершальне перемішування майонезного соусу.

Таблиия 3. Рецептури майонезних соусів (у відсотках)

\begin{tabular}{|c|c|c|c|c|c|}
\hline \multirow{2}{*}{$\begin{array}{c}\text { № } \\
\text { п/п }\end{array}$} & Назва компоненту & \multicolumn{4}{|c|}{ Зразки майонезних соусів } \\
\cline { 3 - 6 } & 2 & 3 & 4 & 5 & 6 \\
\hline 1 & $\begin{array}{c}\text { Рафінована дезодорована соняшникова } \\
\text { олія МIGROS }\end{array}$ & 65 & - & - & - \\
\hline 1 & $\begin{array}{c}\text { Рафінована дезодорована високоолеїнова } \\
\text { соняшникова олія ВIO СООР }\end{array}$ & - & 65 & - & - \\
\hline
\end{tabular}




\begin{tabular}{|c|c|c|c|c|c|}
\hline \multicolumn{5}{c}{ Продовженн табл. 3} \\
\hline 1 & 2 & 3 & 4 & 5 & 6 \\
\hline 3 & $\begin{array}{c}\text { Рафінована дезодорована арахісова олія } \\
\text { MIGROS }\end{array}$ & - & - & 65 & - \\
\hline 4 & $\begin{array}{c}\text { Рафінована дезодорована ріпакова } \\
\text { високоолеїнова олія MIGROS }\end{array}$ & - & - & - & 65 \\
\hline 5 & Рідкий яєчний білок & 4 & 4 & 4 & 4 \\
\hline 6 & Гірчиця готова & 3 & 3 & 3 & 3 \\
\hline 7 & Цукор-пісок & 1,5 & 1,5 & 1,5 & 1,5 \\
\hline 8 & Сіль & 1 & 1 & 1 & 1 \\
\hline 9 & Кислота оцтова (9,0\%) & 3,5 & 3,5 & 3,5 & 3,5 \\
\hline 10 & Вода & до 100 & до 100 & до 100 & до 100 \\
\hline
\end{tabular}

У виготовлених зразках майонезних емульсій з рідким яєчним білком та масовою часткою олії $65,0 \%$ досліджували зміну стійкості емульсії за умов центрифугування протягом 2-7 хвилин при частоті обертання $3000 \mathrm{xв}^{-1}$ за температури $25^{\circ} \mathrm{C}$ (рис. 1 ).

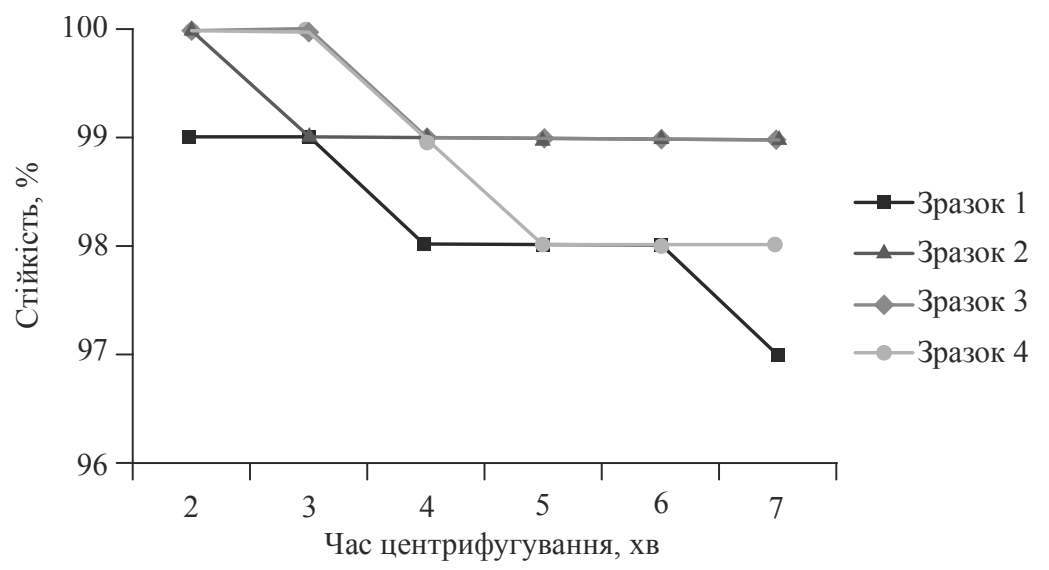

Рис. 1. Зміна стійкості емульсії дослідних зразків

За отриманими даними (рис. 1) для розробленої методики визначення стійкості обираємо час центрифугування 5 хв при частоті обертання $3000 \mathrm{xB}^{-1}$.

3 літературних джерел відомо, що денатурація білка курячих яєць відбувається на різних температурних рівнях, але починається при температурі $55^{\circ} \mathrm{C}$. Для яєчного білка діапазони температур пастеризації становлять 56$58^{\circ} \mathrm{C}$. Тому для вивчення термостабільності майонезних емульсій 3 використанням рідкого яєчного білка обрано температуру $55 \pm 1^{\circ} \mathrm{C}$.

На другому етапі було досліджено термостабільність майонезних емульсій 3 використанням рідкого яєчного білка та масовою часткою олії $65 \%$ при температурі $55 \pm 1{ }^{\circ} \mathrm{C}$ при витримуванні $2-20$ хв 3 попереднім та остаточним центрифугуванням протягом 5 хв при $3000 \mathrm{xв}^{-1}$ (рис. 2).

За даними графіка для розробленої методики визначення стійкості емульсії з урахуванням термостабільності приймаємо час витримування 10 хв при $55 \pm 1^{\circ} \mathrm{C}$ у термостаті. 


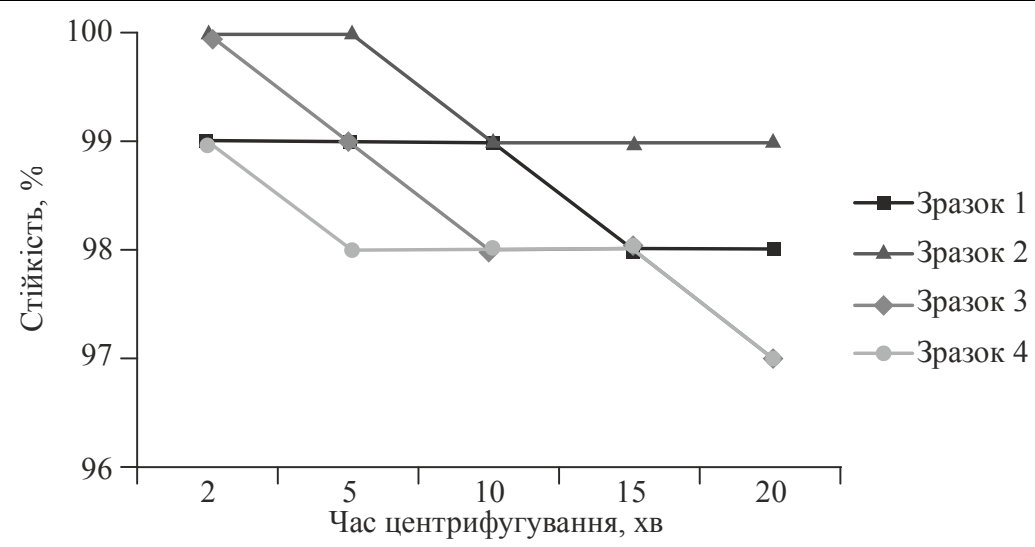

Рис. 2. Зміна стійкості емульсії в зразках майонезних емульсій

Розроблена методика визначення стійкості емульсії (у відсотках незруйнованої емульсії) передбачає попереднє центрифугування зразка майонезної емульсії в скляній пробірці, що заповнюють до верхньої поділки 10 мл, протягом 5 хв при частоті обертання $3000 \mathrm{xв}^{-1}$ та витримуванні в термостаті протягом 10 хв при $55 \pm 1{ }^{\circ} \mathrm{C}$ з остаточним центрифугуванням протягом 5 хв.

За розробленою методикою за остаточний результат визначення приймають середнє арифметичне результатів двох паралельних визначень. Обчислення проводять до першого десяткового знака 3 подальшим зведенням результату до цілого числа.

Методом статистичної обробки визначено, що розбіжність між двома паралельними визначеннями за достовірної ймовірності 0,95 не перевищує $2,0 \%$ (абс). Межа можливих значень похибки вимірювання за достовірної ймовірності 0,95 складає $\pm 3,0$ (абс).

Вихідним параметром, за яким регулювали процес, прийнята $y$ - стійкість емульсії,\%, а факторами: $x_{1}$ - вміст рафінованої дезодорованої соняшникової олії,\% $x_{2}$ - вміст емульгатора (рідкий яєчний білок), $\% x_{3}$ - вміст гірчиці, $\%$

Регресійна модель була побудована за допомогою пакета STATISTICA V.7. Перевірено на значущість коефіцієнти моделі ( $<0,05)$, коефіцієнт детермінації $\kappa=0,988[6]$ :

$$
y=-2,77+1,39 \cdot x_{1}+17,22 \cdot x_{2}+1,16 \cdot x_{3}-0,24 \cdot x_{1} \cdot x_{2} .
$$

Кількість факторів не дає змогу візуалізувати поверхню відгуку в $R^{3}$. Але за виглядом функції видно, що іiі мінімум і максимум досягаються на границі області значень експерименту.

Таблиця 4. Рівні варіювання факторів оптимізації

\begin{tabular}{|c|c|c|c|c|}
\hline \multirow{2}{*}{ Найменування рівня } & \multirow{2}{*}{ Позначення } & \multicolumn{3}{|c|}{ Фактори } \\
\cline { 3 - 5 } & & $x_{1}, \%$ & $x_{2}, \%$ & $x_{3}, \%$ \\
\hline Верхній & + & 68 & 5 & 4 \\
\hline Середній & 0 & 65 & 4 & 3 \\
\hline Нижній & - & 62 & 3 & 2 \\
\hline Крок & $\Delta$ & 3 & 1 & 1 \\
\hline
\end{tabular}


Показник стійкості емульсії (функція відгуку) має бути не менше 97\%, тобто має виконуватись умова:

$$
97<=-2,77+1,39 \cdot x_{1}+17,22 \cdot x_{2}+1,16 \cdot x_{3}-0,24 \cdot x_{1} \cdot x_{2} .
$$

Остання нерівність, зокрема, еквівалентна такій:

$$
x_{1} \geq \frac{99,77-17,22 x_{2}-1,16 x_{3}}{1,39-0,24 x_{2}} .
$$

Очевидно, нерівність (1) задовольняють тільки ті точки $\vec{x}=\left(x_{1}, x_{2}, x_{3}\right) \in R^{3}$, що лежать на поверхні, а також над поверхнею:

$$
f\left(x_{2}, x_{3}\right)=\frac{99,77-17,22 x_{2}-1,16 x_{3}}{1,39-0,24 x_{2}} \text { в } R^{3} .
$$

Розв'язуючи рівняння $\frac{99,77-17,22 x_{2}-1,16 x_{3}}{1,39-0,24 x_{2}}-x_{1}=0$ відносно $x_{2}$ при фіксованих $x_{1}$ i $x_{3}$, отримаємо таблицю (табл. 5) залежності граничної кількості білка від кількості олії та гірчиці, що гарантовано забезпечуватиме стійкість емульсії.

Таблиия 5. Експериментальні дані для побудови поверхні відгуку

\begin{tabular}{|c|c|c|c|c|c|}
\hline & 2 & 2,5 & 3 & 3,5 & 4 \\
\hline 62 & 4,82 & 4,57 & 4,33 & 4,07 & 3,82 \\
\hline 63 & 4,7 & 4,43 & 4,15 & 3,87 & 3,6 \\
\hline 64 & 4,56 & 4,25 & 3,94 & 3,63 & 3,32 \\
\hline 65 & 4,38 & 4,02 & 3,66 & 3,31 & 2,95 \\
\hline 66 & 4,14 & 3,71 & 3,3 & 2,88 & 2,46 \\
\hline 67 & 3,79 & 3,28 & 2,77 & 2,26 & 1,75 \\
\hline 68 & 3,25 & 2,61 & 1,96 & 1,32 & 0,67 \\
\hline
\end{tabular}

За першим рядком таблиці можна визначити вміст рідкого білка, що забезпечує стійкість емульсії (це є максимум, що досягається на границі - для значення вмісту рослинної олії $62 \%$ ).

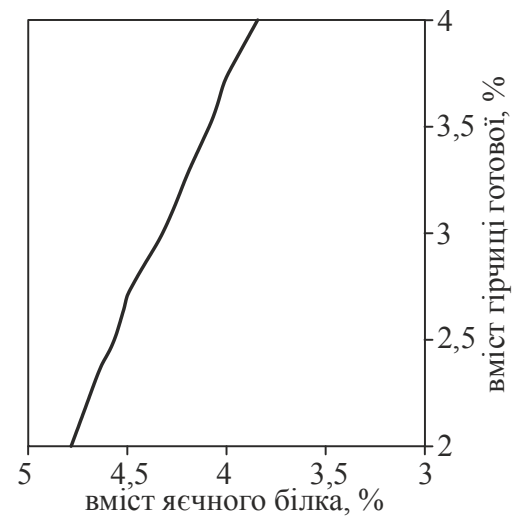

Рис. 3. Перетин із площиною, вміст олії-62,0\% 
3 рис. 3 видно, що стійкість емульсії забезпечується для значень вмісту рідкого яєчного білка у широкому діапазоні $[4 ; 5]$ з урахуванням похибки та відповідної рецептурної кількості гірчиці та інших рецептурних компонентів, що використовувалися в експерименті.

У майонезних продуктах, що готували за розробленими рецептурами $[5$, с. 3$]$ на основі олій з різним жирнокислотним складом з використанням рідкого яєчного білка як емульгатора, визначали основні органолептичні та фізикохімічні показники якості за стандартними методиками, за винятком показника стійкості емульсії, що визначали за розробленим спеціальним методом.

Результати досліджень органолептичних та фізико-хімічних показників майонезних продуктів з використанням рідкого яєчного білка представлені в табл. 6.

Таблиия 6. Результати досліджень показників майонезів

\begin{tabular}{|c|c|c|c|c|c|}
\hline \multirow{2}{*}{ № ח/п } & \multirow{2}{*}{ Назва показника } & \multicolumn{4}{|c|}{ Зразок } \\
\hline & & 1 & 2 & 3 & 4 \\
\hline 1 & Консистенція, зовнішній вигляд & \multicolumn{4}{|c|}{ Однорідний сметаноподібний продукт } \\
\hline 2 & Смак і запах & \multicolumn{4}{|c|}{$\begin{array}{c}\text { Притаманний майонезному продукту типу } \\
\text { «Провансаль» }\end{array}$} \\
\hline 3 & Колір & \multicolumn{4}{|c|}{ Біло-кремовий, однорідний } \\
\hline 4 & Масова частка жиру, \% & 65,5 & 65,5 & 65,5 & 65,5 \\
\hline 5 & $\begin{array}{c}\text { Масова частка яєчних } \\
\text { продуктів, у тому числі } \\
\text { ферментованих, у перерахунку } \\
\text { на сухий яєчний жовток, \%. }\end{array}$ & \multicolumn{4}{|c|}{ Відсутні } \\
\hline 6 & Масова частка вологи, \% & 30,1 & 30,1 & 30,1 & 30,0 \\
\hline 7 & $\begin{array}{c}\text { Кислотність, (\%, на оцтову } \\
\text { кислоту) }\end{array}$ & 0,37 & 0,39 & 0,38 & 0,36 \\
\hline 8 & $\begin{array}{c}\text { Стійкість емульсії за } \\
\text { спеціальною методикою, (\% } \\
\text { незруйнованої емульсії) }\end{array}$ & 99 & 99 & 98 & 98 \\
\hline
\end{tabular}

Із даних табл. 6 можна зробити висновок, що майонези на основі олій різного жирнокислотного складу з рідким яєчним білком мають високі показники якості.

\section{Висновки}

1. Оптимізовано рецептуру майонезних продуктів з використанням рідкого яєчного білка за показником стійкості емульсії, що визначають за допомогою розробленого спеціального методу. Досліджено синергізм дії емульгаторів у високожирних емульсіях: яєчного білка та гірчичного порошку, що проявляється у підвищенні стійкості емульсії.

2. Розроблено спеціальний метод визначення стійкості емульсії (у відсотках незруйнованої емульсії) для майонезних емульсій на основі рідких олій різного жирнокислотного складу з рідким яєчним білком, що передбачає попереднє центрифугування зразка майонезної емульсії в пробірці протягом 5 хв при $3000 \mathrm{xB}^{-1}$ при температурі $25^{\circ} \mathrm{C}$ та витримування в термостаті 10 хв при $55 \pm 1^{\circ} \mathrm{C} 3$ остаточним центрифугуванням 5 хв. 
3. Рекомендовано рецептури емульсійних продуктів на основі олій різного жирнокислотного складу 3 рідким яєчним білком. Показано, що майонезні продукти на основі олій різного жирнокислотного складу з рідким яєчним білком, що не містять холестерину, мають високі показники якості.

\section{Література}

1. ДСТУ 4560:2006 «Майонези. Правила приймання та методи випробування» [Чинний від 2008-01-01]. — Київ : Держспоживстандарт України, 2008. — 16 с. — (Національний стандарт України).

2. Бабенко B.I. Технологія майонезів на основі яйце продуктів / B.I. Бабенко, В.О. Бахмач, О.А. Прудиус // Продукты \& Ингредиенты. —2012. — № 1. — С. 40- 41.

3. Бабенко B.I. Використання натуральних емульгуючих компонентів в технології майонезів / В.І. Бабенко, В.О. Бахмач, I.І. Строй // Перспективи розвитку м'ясної, молочної та олієжирової галузей у контексті євроінтеграції: програма та матеріали VI міжнар. наук.-техн. конф. - Київ, 2015. - С. 169-170.

4. Бахмач В.О. Удосконалення технології майонезів з використанням рослинної сировини / В.О. Бахмач, Л.В. Пешук // Харчова промисловість. — 2015. - Вип. 18. - С.27-31.

5. Бабенко B.I. Майонезний емульсійний продукт / В.І. Бабенко, В.О. Бахмач, О.В. Поросюк // Патент України на корисну модель № 122188, Держреєстр патентів України на корисні моделі, Бюл. № 24, 26.12.2017.

6. Міхайленко В.M. Теорія ймовірностей, ймовірнісні процеси та математична статистика / В.М. Міхайленко, С.А. Теренчук, О.О. Кубайчук // Навчальний посібник. - Київ : 2007. $-163 \mathrm{c}$. 